\title{
Sesje Kapituły Katedralnej Wileńskiej w okresie przedrozbiorowym
}

\section{SESSIONS HELD BY THE VILNIUS CATHEDRAL CHAPTER BEFORE THE PARTITION OF POLAND}

Cathedral chapters were colleges appointed to help bishops govern their dioceses. As such, they functioned according to collegiate principles. These principles presupposed that all decisions were to be made during collegiate meetings, which were generally referred to as sessions or chapters. These meetings primarily served as a means for the participants to come to mutual agreements and to adopt appropriate resolutions regarding how the chapter functioned as a college and its activities outside of the college. The Cathedral Chapter of Vilnius modeled itself after the royal chapter. From the 15th to the 18th centuries, the general chapter sessions and individual meetings, which included both weekly sessions as well as extraordinary sessions that convened to discuss pressing matters, took place two to three times each year on specific days. The extraordinary sessions also included urgent meetings known as sessiones repertinae, which differed from the other sessions primarily because of topics they addressed, the type of resolutions that were to be adopted, how frequently these resolutions were to be implemented, and the extent to which the prelates and canons were obliged to be present. During the pre-conciliar period, the meetings of the general Vilnius chapter were occasions to discuss and resolve more important and essential matters in accordance with statutes and adopted practices, while the individual sessions were dedicated to less important matters and often dictated by the college's ongoing needs. 
Key words: Vilnius, Diocese of Vilnius, cathedral chapter, general chapter session, particular chapter session, college of clerics, chapter notary, prelate, canon.

Kapituły katedralne w Kościele katolickim w XII i XIII wieku były już autonomicznymi korporacjami duchownych, posiadającymi osobowość prawną, własne statuty i dobra beneficjalne. Wspierały one biskupa w zarządzie diecezją. Jako takie zatem funkcjonowały na zasadach przyjętych w korporacjach, co zakłada, że wszelkie decyzje dotyczące ich i zarządu diecezją w granicach zakreślonych normami prawa kościelnego, zwłaszcza wiążące wszystkich członków, były podejmowane kolegialnie na wspólnych posiedzeniach, zwanych ogólnie sesjami lub kapitułami. Służyły one przede wszystkim wzajemnemu porozumieniu i podjęciu odpowiednich uchwał dotyczących funkcjonowania kapituły zarówno w zakresie jej zadań jako kolegium, jak też jej aktywności zewnętrznej ${ }^{1}$. Nieocenionym źródłem dla odtworzenia organizacji sesji i ich przebiegu są głównie spisywane przez notariusza protokoły, stanowiące zasadniczą część kapitulnej księgi wpisów.

Obowiązek odbywania sesji kapitulnych płynął z nakazu prawa tak powszechnego, jak i partykularnego. Wspólne zgromadzenia członków kapituły przewidywała już reguła akwizgrańska, a następnie, już w szerszym zakresie, zaistniały one w prawie dekretałów ${ }^{2}$. Na ziemiach polskich posiedzenia kapituł odbywały się już w XI i XII wieku, gdy wymagała tego konieczność rozstrzygnięcia ważnej sprawy ${ }^{3}$. Z czasem

History of the Church praktyka odbywania tego rodzaju zebrań została usankcjonowana przepisami prawa synodalnego, zwłaszcza prowincjalnego. Drugi Synod Łęczycki z 1523 roku oraz Synod Piotrkowski z roku 1545 wyraźnie domagały się odbywania posiedzeń kapituł katedralnych ${ }^{4}$.

Kapituła Katedralna Wileńska wzorując się w swym działaniu i organizacji na kapitułach koronnych, zwłaszcza Kapitule Katedralnej

$1 \quad$ D. Bouix, Tractatus de capitulis, Parisiis - Lugduni 1852, s. 182, 374-378.

$2 \quad$ S. Zachorowski, Rozwój i ustrój kapitut polskich w wiekach średnich, Kraków 1916, s. 158; P. Pałka, Posiedzenia katedralnej kapituty chetmskiej obrzędu tacinskiego wświetle materiałów archiwalnych, „Roczniki Teologiczno-Kanoniczne” 19(1972), z. 5, s. 2

3 W. Góralski, Posiedzenia kapituty kolegiackiej w Puttusku (XV-XX w.), „Studia Płockie", 4(1976), s. 185.

4 Constitutiones synodorum Metropolitanae Ecclesiae Gnesnensis provincialium, red. J. Wężyk, Cracoviae 1630, s. 141-142; B. Ulanowski, Materiaty do historii ustawodawstwa synodalnego w Polsce w XVI w., [w:] Archiwum Komisji Prawniczej, t. 1, Kraków 1895, s. 402. 
Krakowskiej, odbywała sesje generalne oraz posiedzenia partykularne, przez które rozumiano zarówno regularnie odprawiane sesje cotygodniowe, jak też sesje nadzwyczajne zwoływane dla omówienia spraw niecierpiących zwłoki. Do tych ostatnich należy też zaliczyć posiedzenia zwoływane w trybie pilnym, tzw. sessiones repertinae. Różniły się one głównie zakresem kompetencji określanych przedmiotem obrad, rodzajem podejmowanych uchwał, częstotliwością ich odprawiania i stopniem zobowiązania prałatów i kanoników do obecności.

\section{Sesje generalne}

Istotnymi dla funkcjonowania kapituły były sesje generalne. Braki materiału źródłowego, zwłaszcza protokołów posiedzeń dla końca wieku XIV i całego wieku XV nie pozwalają na jednoznaczne określenie, kiedy one ostatecznie się wyodrębniły, uformowały i przejęły określone kompetencje. Materiał archiwalny późniejszej proweniencji skłania ku przypuszczeniu, iż działo się to drogą ewolucji w trakcie kształtowania się form organizacyjnych kapituły, dookreślania jej ustroju i rozwoju podstaw materialnych. Ważnym pod tym względem wydaje się być zapis w księdze protokołów uczyniony 13 grudnia 1513 roku. Wynika zeń, że z powodu trudności związanych z zebraniem na posiedzenia wszystkich członków kapituły, podjęto uchwałę, zobowiązującą wszystkich prałatów i kanoników do obecności na trzech sesjach generalnych w roku (ad tria generalia capitula). Miały one rozpoczynać się: pierwsza po uroczystości Matki Bożej Gromnicznej (2 lutego), druga po uroczystości podniesienia relikwii św. Stanisława Biskupa Męczennika, ustalonej w Polsce na 8 maja oraz trzecia po uroczystości przeniesienia jego doczesnych szczątków (27 września). Na tejże sesji podjęto uchwałę, mocą której obecność na posiedzeniach zwoływanych w tych trzech terminach stała się obowiązkowa (pod karą grzywny w wysokości trzech groszy litewskich), a decyzje na nich zapadające obowiązywały odtąd wszystkich członków Kapituły, także tych, którzy z różnych względów w obradach nie brali udziału 5 .

$\mathrm{Z}$ czasem zredukowano liczbę sesji do dwóch, rezygnując z sesji zimowej. W świetle dostępnych źródeł trudno dokładnie określić, kiedy to się stało, faktem jest, że w zbiorze statutów z 1584 roku o sesji zimowej nie wspomina się ani słowem, mimo że problematyce posiedzeń 
generalnych poświęcono aż cztery rozdziały ${ }^{6}$. Inny natomiast jest tenor ksiąg protokołów sesji, gdzie do połowy XVII stulecia wyraźnie, niemal każdego roku, odnotowywano uchwały sesji generalnych zimowych. Zaniechano ich z całą pewnością po najeździe moskiewskim i powrocie kapituły do Wilna w 1662 roku. Wówczas ślad po zimowych sesjach generalnych w księgach kapitulnych ginie. Jeżeli w porze zimowej odbywały się jakieś posiedzenia, były to wyraźnie sesje partykularne. Jednakże uchwałę w sprawie dwóch sesji generalnych w ciągu roku kapituła podjęła dopiero w 1712 roku, po tym jak w trakcie zarazy w Wilnie w 1710 roku kapituła zrezygnowała z sesji jesiennej i starym zwyczajem odprawiła ją po 2 lutego roku następnego tłumacząc, że w zimie morowe powietrze „nieco ustało”. Nie na tyle jednak, by członkowie kapituły poczuli się dość bezpiecznie, gdyż odprawiono wówczas tylko jedno posiedzenie, po czym całe gremium solidarnie z miasta uciekło $^{7}$. Do wydarzenia tego kapituła nawiązała na sesji wiosennej w 1712 roku, kiedy to podjęto uchwałę, że za generalne będą uważane tylko i wyłącznie dwie sesje w roku, odprawione w przepisanych dla nich terminach: po 8 maja jedna i po 27 września druga ${ }^{8}$. W 1742 roku zmieniono nieco termin sesji generalnej wiosennej, określając jej początek na dzień po uroczystości św. Jerzego (w Polsce - 24 kwietnia), argumentując tę decyzję taką to okolicznością, że maj jest bardziej stosownym czasem na regenerację skołatanego zimowymi trudami zdrowia, niż na wielogodzinne rozstrzyganie istotnych spraw w mało wygodnym kapitularzu. Nietrafioną i zupełnie niepraktyczną uznano także propozycję biskupa, by obrady sesji generalnych połączyć

History of the Church z uroczystością św. Kazimierza, bo - jak argumentowano - dni są jeszcze krótkie, pochmurne, a pogoda kapryśna ${ }^{9}$. Terminy sesji generalnych starano się zachować nawet na tułactwie w okresie najazdu moskiewskiego ${ }^{10}$, czy okupacji Wilna przez wojska szwedzkie podczas

$6 \quad$ BLAN,f.43-155, Statuta inclitae Ecclesiae Cathedralis tam a Venerabili Capitulo quam eius Pontificibus edita tum a Sanctissima Sede Apostolica confirmata, [ok. 1584], k. 22-23v.

BLAN, f43-229, ACV, t. 21 (1709-1717), s. 28.

8 Ibidem, s. 54.

$9 \quad$ BLAN, f.43-234, ACV, t. 26 (1739-1744), s. 286.

10 Poopuszczeniu Wilna kapituła w liczbie czterech członków zebrała się na pierwszej sesji w dobrach kapitulnych w Braszewiczach 3 lutego 1656 roku. Nadano jej rangę sesji generalnej, gdyż większość pozostałych członków rozproszonego kolegium kapitulnego przysłała swe pełnomocnictwa. BLAN, f.43-221, ACV, t. 13 (1652-1663), k. 200-200v.; Kolejną sesję, również w Braszewiczach odprawiono w roku następnym, także zimą, od 5 lutego, kolejne zaś: 23 lipca 1657 roku w Dereczynie, w pierwszych dniach października 1657 roku w Brześciu 
Wojny Północnej ${ }^{11}$. Dopiero 7 maja 1760 roku, za konsensusem biskupa, przeniesiono ostatecznie i definitywnie termin rozpoczęcia obrad na poniedziałek po pierwszej niedzieli Wielkiego Postu. Powodem tej decyzji była okoliczność, że akurat w maju obradował Trybunał Główny Litewski, na który z racji na ważkość zapadających tam decyzji dotyczących spraw kapituły, powinna być ona na ów czas w pełni dyspozycyjna ${ }^{12}$.

Termin rozpoczęcia sesji generalnej podawano odpowiednio wcześniej poprzez ogłoszenia z ambony w kościołach wileńskich. Ponadto, zgodnie ze statutami, stosowne obwieszczenie przytwierdzał prokurator kapitulny do drzwi katedry na miesiąc przed rozpoczęciem obrad. W piśmie tym znajdowało się, oprócz informacji o dniu rozpoczęcia sesji, także wyraźne przypomnienie skierowane do wszystkich członków kapituły o bezwzględnym obowiązku obecności na wszystkich posiedzeniach i wymieniono sankcje karne przewidziane dla nieobecnych. Nieusprawiedliwiona absencja skutkowała nie tylko niewypłaceniem konsolacji przysługującej obradującym na sesjach prałatom i kanonikom i karą grzywny w wysokości jednej kopy groszy litewskich. Lekceważący obowiązek udziału w obradach pozbawiany był refekcji przez okres jednego roku, zaś notoryczne uchylanie się od posiedzeń generalnych mogło skutkować także pozbawieniem rocznych dochodów z prestymonium. Za nieobecnych uznawano też tych, którzy bez ważnej przyczyny spóźnili się na obrady, uczestniczyli tylko w ich części lub przed zakończeniem obrad sesję opuścili. Tak stanowiły statuty ${ }^{13}$. W praktyce owe najsurowsze sankcje, jeżeli były stosowane, to wyjątkowo rzadko, gdyż nieobecni na sesji członkowie kapitulnego gremium znajdowali zwykle jakieś usprawiedliwienie swej absencji, które współbracia, nie wnikając w szczegóły, przyjmowali do wiadomości i nakładali co najwyżej grzywnę i karę pozbawienia refekcji na pewien czas, rzadko na okres całego roku. Protokoły odnotowują zaledwie kilka przypadków odjęcia z tego powodu dochodów z dóbr prestymonialnych i to w przypadkach notorycznego zaniedbywania obowiązków przy katedrze lub czynów skutkujących karami przewidzianymi przez kanony prawa kościelnego lub ustawy prawa

Litewskim, w maju 1658 roku w Braszewiczach, od 30 września t.r. w Różanie, od 9 maja 1659 roku w Słonimie, kolejne trzy sesje (od 30 września 1659, od 10 maja 1660, od 24 marca 1661) w Różanie, od 15 lipca 1661 roku w Warszawie, we wrześniu 1661 roku w Żyrowicach i w Różanie. Ibidem, k. 219-297.

BLAN, f.43-228, ACV, t. 20 (1698-1709), passim. 
świeckiego ${ }^{14}$. Za usprawiedliwionych uważano obłożnie chorych i tych, którzy w imieniu kapituły pełnili jakiekolwiek legacje ${ }^{15}$. W przypadku przewidzianej wcześniej usprawiedliwionej nieobecności winni oni przekazać swe pełnomocnictwa jednemu ze współbraci, który na sesji występował w jego imieniu, zabierał głos w dyskusji, brał udział w głosowaniach i dopełniał innych aktów, które jawiły się podczas obrad $^{16}$. Prokurator, lub w jego zastępstwie notariusz, miał obowiązek powiadomić chorych oraz będących poza Wilnem członków kapituły o terminie rozpoczęcia sesji ${ }^{17}$.

Sesje generalne rozpoczynano w oznaczonym dniu Mszą św. o Duchu Świętym odprawianą w kaplicy św. Kazimierza. Następnie gremialnie, z zachowaniem procedencji, udawano się do kapitularza, gdzie po zajęciu właściwych sobie miejsc, śpiewano hymn Veni Creator, a odgłos dzwonów katedralnych obwieszczał wszem i wobec, że posiedzenia właśnie się rozpoczęły ${ }^{18}$. W ten sposób oznajmiano rozpoczęcie obrad każdego dnia sesji, podczas gdy prałaci i kanonicy odmawiali modlitwę do Ducha Świętego z odpowiednią antyfoną o uproszenia ducha braterskiej zgody i wzajemnego zrozumienia ${ }^{19}$. Zasadniczą część obrad rozpoczynano od wyboru, drogą głosowania, przewodniczącego sesji. Mógł nim zostać każdy aktualny członek kapituły. W praktyce wybierano zwykle jednego z prałatów, najczęściej najstarszego stażem kapitulnym, święceniami lub wiekiem. Taki stan rzeczy z czasem nie przypadł do gustu części grona kanoników, którzy na sesji generalnej wiosennej w 1683 roku oprotestowali ten zwyczaj domagając się podjęcia uchwały, by na prezydentów obrad wybierać na przemian prałata

History of the Church i kanonika. Prałaci na ten postulat odpowiedzieli krótko i rzeczowo, że kanonicy są sami sobie winni, gdyż w kapitule jest ich dwukrotnie więcej, niż prałatów, zatem przy pewnej jednomyślności zawsze są w stanie wybrać przewodniczącego spośród siebie, ponieważ wybór

$14 \quad$ Charakterystycznym, aczkolwiek należącym do nielicznych wyjątków przypadkiem była sprawa kanonika Franciszka Kryszpina, którego pozbawiono prawa wejścia na sesje kapitulne i zatrzymano wszelkie dochody za to, że nie bywał na sesjach generalnych, zaniedbał dobra prestymonialne, wypędził stamtąd poddanych etc. W liście skierowanym do jego ojca kapituła zaleca, by ten, mając nad synem ,authoritas”, „dla uniknięcia dalszych excessów”, wziął go do siebie i „przytrzymał”. BLAN, f.43-225, ACV, t. 17 (1673-1681), s. 366, 439.

15 BLAN, f.43-155, Statuta, [ok. 1584], k. 23.

BLAN, f.43-226, ACV, t. 18 (1683-1685), s. 39.

BLAN, f.43-213, ACV, t. 5 (1570-1578), k. 51.

BLAN, f.43-155, Statuta, [ok. 1584], k. 23.

BLAN, f.43-210, ACV, t. 1-2 (1502-1546), k. 21-21v. 
dokonuje się drogą głosowania, w którym każdy głos ma jednakową wartość. W świetle powyższego dziwnym wydaje się złożenie projektu takiej ustawy. W rzeczywistości kanonicy w głosowaniu jawnym oddawali swe głosy na prałatów nie tylko z racji na ich kompetencje i należny szacunek, lecz zapewne i dlatego, by nie narażać się na niechęć stojących od nich wyżej konfratrów - prałatów, wśród których nierzadko większość było biskupami sufraganami diecezji wileńskiej i diecezji sąsiednich. Zadekretowanie postulowanego porządku zażegnałoby ową drażliwą kwestię, jednak stosownej, sankcjonującej nowy porządek uchwały nie poddano nawet pod głosowanie ${ }^{20}$.

Wybrawszy przewodniczącego (prezydenta) sesji rozpoczynano formalne czynności wstępne: poddawano analizie listę nieobecnych członków kapituły, roztrząsano sprawę ich absencji i powody, dla których nie przybyli, po czym prokurator lub notariusz odczytywał aktualne statuty kapituły, konstytuowano legację do biskupa lub wysyłano doń listy z oznajmieniem rodzaju spraw mających być omawianymi na posiedzeniach, by ten mógł ewentualnie wnieść swoje postulaty i uwagi, wyznaczano delegatów mających odwiedzać podczas obrad chorych konfratrów ${ }^{21}$. Po załatwieniu tych formalności przystępowano do zasadniczej części obrad. Na sesjach generalnych rozstrzygano sprawy ważniejsze, a postanowienia tam zapadłe miały moc prawa. Podejmowano zatem decyzje dotyczące spraw majątkowych kapituły, przyjmowano fundacje, inne nadania, dokonywano zmian w funduszach, decydowano o inwestycjach i kontraktach. Osobną materią obrad były sprawy konsensusu kapituły i biskupa w tych obszarach, gdzie zachodziły różnice zdań w kwestiach zasadniczych, zwykle majątkowych, ale też personalnych i dotyczących decyzji odnoszących się do jej zarządu tak in spiritualibus, jak in temporalibus. Kolejny blok tematów to sprawy procesowe z osobami świeckimi oraz kwestie nadań i przywilejów. Stałym punktem obrad były też kwestie dotyczące funkcjonowania kapituły jako korporacji samej w sobie ${ }^{22}$. Ponieważ zapadające na sesjach decyzje niosły konkretne skutki prawne, sporządzano dokumenty na pergaminie uwierzytelniane pieczęcią wielką przechowywaną w skrzyni i zabezpieczoną pieczęciami wszystkich członków kapituły. Można jej było używać jedynie na sesjach generalnych ${ }^{23}$. Stąd

$20 \quad$ BLAN, f.43-226, ACV, t. 18 (1683-1685), s. 37.

21 BLAN, f.43-155, Statuta, [ok. 1584] (De legendis statutis in capituli generalis initio), k. 23.

22 BLAN, f.43-210, ACV, t. 1-2 (1502-1546), k. 28-29; BLAN, f. 43-237, ACV, t. 29 (1767-1777), s. 231-232.

$23 \quad$ BLAN, f.43-210, ACV, t. 1-2 (1502-1546), k. 92. 
m.in. tak ważna była stuprocentowa frekwencja na posiedzeniach i pełnomocnictwa wydawane przez nieobecnych. Pieczęć można było złamać tylko za zgodą tego, który ją przyłożył. Dokumenty mniejszej wagi uwierzytelniano pieczęcią małą, którą przechowywał prokurator lub notariusz. Jej także używano jedynie na sesjach generalnych ${ }^{24}$.

Sesje przeciągały się w nieskończoność, trwały całe tygodnie, nierzadko kilka miesięcy, co było powodem „próżnej straty czasu i tęsknicy" (tzn. nudy). Na wiosennej sesji generalnej w 1770 roku przyjęto więc zmodyfikowany porządek obrad. Przede wszystkim określono czas trwania sesji na osiem dni. W tym okresie prałaci i kanonicy powinni byli na tyle przyłożyć się do pracy, by załatwić wszystkie wcześniej zaplanowane sprawy. Jedynie w wyjątkowych sytuacjach termin ten mógł być przedłużony, ale tylko o kilka dni. Skończono także z sesjami ciągnącymi się przez cały dzień i określono czas trwania posiedzenia na trzy, potem na dwie godziny w ciągu dnia. Debata winna rozpocząć się o godz. 9.00 lub 10.00, a zakończyć o godz. 12.00. Wybrany na pierwszej sesji prezydent powinien każdego następnego dnia rozpoczynać obrady punktualnie, nawet w obecności tylko trzech uprawnionych do wotowania członków kapituły, nie narażając się przy tym na zarzut nieważności podjętych w tym gronie uchwał ${ }^{25}$. O tym, że był to przepis trafny i zasadny świadczy fakt potwierdzony przez akta posiedzeń, że odtąd niemal wszyscy debatujący w obawie, aby podczas ich nieobecności nie zapadły decyzje dla nich niekorzystne, punktualnie stawiali się w kapitularzu. Po wyborze prezydenta, przeczytaniu statutów i akt ostatniej sesji, natychmiast należało przejść do rzeczy i przedstawić porządek obrad. Aby te przebiegały sprawnie, prokurator, który rozpoczynał tę część posiedzenia i w największym skrócie referował sprawy procesowe, winien do wystąpienia wcześniej solidnie się przygotować poprzez sporządzenie rejestru tychże spraw w specjalnej dla tego celu założonej księdze. Następnie podkustosz referował stan kapitulnej kasy. Kwestię tę przedstawiał krótko, ale treściwie w oparciu o informacje, które wcześniej przygotował i odnotował w księdze finansowej. Materiał do dyskusji w oparciu o treść owych dwóch ksiąg, według porządku spraw w nich zapisanych, podawał prezydent sesji. Stojąc na straży ustalonego porządku dbał, żeby dyskutanci przedstawiali, według ustalonej wcześniej kolejności, swój punkt widzenia brevissimis verbis. Żeby tej części obrad nie przedłużać i skutecznie ostudzić emocje co bardziej krewkich współbraci, wznowiono dotychczasowe ustawy, przewidujące sankcje dla tych,

\footnotetext{
$24 \quad$ Ibidem.

$25 \quad$ BLAN, f. 43-237, ACV, t. 29 (1767-1777), s. 231.
} 
którzy ośmielali się przerywać mówiącemu i wtrącać własne, bywało, że niewybredne w treści i formie uwagi ${ }^{26}$. Każdorazowy tego rodzaju wyczyn kosztował zapalonego nie w porę do dyskusji kapitulnego dostojnika grzywnę w wysokości 1 złp. ${ }^{27}$

W przypadku, gdy podawana do dyskusji sprawa dotyczyła konfratra akurat w kapitularzu nieobecnego, odkładano ją do następnej sesji generalnej. Propozycja uchwały, której nie przyjęto jednomyślnie, była poddawana pod głosowanie, które decydowało o jej przyjęciu lub odrzuceniu. Notariusz sporządzał protokół posiedzenia, w którym zapisywał tylko to, co dyskutanci mu ustnie lub pisemnie zapisać polecali, po czym zamieszczał treść przyjętej uchwały. Ostatni dzień sesji przeznaczony był tylko na czytanie gotowych akt odprawionej sesji $^{28}$. Po ich wysłuchaniu nie było już miejsca na dyskusję, prezydent podpisywał protokół całej sesji, czyniąc tym samym wszystkie zawarte w nim uchwały prawomocnymi. W ten sposób wyprodukowane akta sesji notariusz wciągał następnie do księgi protokołów, którą w swoim czasie podpisywał przewodniczący sesji ${ }^{29}$.

Po zakończonej sesji generalnej członkowie kapituły odprawiali egzekwie za zmarłych konfratrów i dobrodziejów, po czym odbierali wynagrodzenie za czas posiedzeń, zwane konsolacją, oraz należne im refekcje. W 1701 roku każdemu z prałatów i kanonikom wypłacono po 300 złp. refekcji za tydzień obrad. Przewodniczący sesji otrzymał nadto 200 złp. konsolacji, pozostali odebrali z tego tytułu po 100 złp. Notariuszowi przypadło wynagrodzenie w wysokości 50 złp. ${ }^{30}$

\section{Sesje partykularne}

W wyniku obrad sesji zimowej kapituły zatwierdzono jej uchwały 13 grudnia 1513 roku i ustalono, że sesje partykularne cotygodniowe będą odbywały się w każdy piątek, z wyjątkiem tych, w które wypadały uroczystości. Wówczas sesje przenoszono na najbliższy dzień wolny po lub przed uroczystością ${ }^{31}$. Także one zobowiązywały członków kapituły do obecności. Absencja była skrupulatnie odnotowywana i jeżeli nie

$26 \quad$ BLAN, f.43-155, Statuta, [ok. 1584] (De infamantibus et vota in capitulo inerrupentibus), k. 23-23v.

27 BLAN, f.43-227, ACV, t. 19 (1685-1698), s. 84.

BLAN, f. 43-237, ACV, t. 29 (1767-1777), s. 232.

BLAN, f. 43- 238, ACV, t. 30 (1777-1783), k. 133v.

BLAN, f. 43-228, ACV, t. 20 (1698-1709), k. 68.

31 BLAN, f.43-210, ACV, t. 1-2 (1502-1546), k. 21v.; Bibl.PAN.Kr, sygn. 1963, Statuta inclite Ecclesiae cathedralis Vilnensis ac Sacre divi Stanislai sedis tam

History of the Church 
była usprawiedliwiona „słuszną przyczyną”, skutkowała karą grzywny w postaci utraty tygodniowych refekcji ${ }^{32}$. W praktyce frekwencja na owych posiedzeniach była zdecydowanie niższa, niż na sesjach generalnych, jako że zarówno ciężar gatunkowy podejmowanych spraw, niskie sankcje karne, jak i łatwość wymówienia się „,słuszną przyczyną" nie mobilizował członków kapituły do częstszego zaglądania do kapitularza. Nie dziwi zatem uchwała podjęta w czerwcu 1683 roku na wiosennej sesji generalnej, sankcjonująca prawnie sesje partykularne odprawione w obecności co najmniej trzech aktualnych członków kapituły ${ }^{33}$. Jej cotygodniowe posiedzenia służyły głównie rozdziałowi sum refekcyjnych pomiędzy poszczególnych członków, wysłuchiwano sprawozdań z prac nad realizacją uchwał podjętych na ostatniej sesji generalnej, zwłaszcza dotyczących zarządu dóbr stołowych i prestymonialnych, stanu zachowania i ewentualnych postępów w pracach remontowych w kamienicach kapitulnych, zabezpieczenia i pozyskania środków na bieżące potrzeby przy sprawowaniu katedralnej służby Bożej. Jednym z ważniejszych tematów poruszanych na tych sesjach było monitorowanie aktualnego stanu technicznego gmachu świątyni katedralnej i stanu jej wyposażenia: ołtarzy, stalli, organów, ksiąg, paramentów liturgicznych i innych. Istotne pojawiające się uwagi notowano w celu przedstawienia ich na sesji generalnej ${ }^{34}$.

Sesje partykularne, oprócz obowiązkowo regularnie odprawianych obrad piątkowych, zwoływano także w trybie nadzwyczajnym w celu omówienia spraw istotnych, wymagających natychmiastowych rozstrzygnięć. Sesje partykularne nadzwyczajne zwoływał prokurator

History of the Church kapitulny, zaś pod jego nieobecność obowiązek ten spoczywał na najstarszym stażem kanoniku ${ }^{35}$. Materię obrad stanowiły sprawy, które nie niosły za sobą skutków prawnych, z wyjątkiem tych, co do których decyzje należało podjąć natychmiast. W takiej sytuacji podejmowano odpowiednie uchwały z zastrzeżeniem, że zostaną one zatwierdzone na najbliższej sesji generalnej. Uczestnicy obrad partykularnych nie byli władni dokonywać rozstrzygnięć ważnych z punktu widzenia ich skutków prawnych, jeżeli mogły być odłożone do obrad generalnych. Zastrzeżenie to obowiązywało pod sankcją nieważności podjętych uchwał. Owe ustalenia zachowywano dość konsekwentnie

a venerabili Capitulo, quamcuius pontificalibus edita et a Sma Sede Apostolica confirmata A. 1515.

BLAN, f. 43-218, ACV, t. 10-11 (1632-1645), k. 91.

BLAN, f. 43- 226, ACV, t. 18 (1683-1685), s. 36.

BLAN, f. 43, ACV, passim.

BLAN, f. 43-225, ACV, t. 17 (1673-1681), s. 25. 
do połowy XVII stulecia, jako że w aktach brak jakichkolwiek wyraźnych wzmianek o praktykach, które by tak ustalony porządek burzyły. Jeżeli zdarzały się, to miały charakter incydentalny. Dopiero analiza materiału archiwalnego późniejszej proweniencji skłania do wniosku, że w rzeczonej materii zaczęło dziać się gorzej, na tyle źle, że kapitulne gremium zebrane na sesji generalnej jesiennej w $1675 \mathrm{r}$. uznało za konieczne zająć w tej sprawie głos. Tak więc 7 października przypomniano kompetencje sesji partykularnych i w dość ostrych słowach napomniano tych, którzy zgromadzenia te ośmielają się wykorzystywać dla załatwienia spraw, co do których trudno byłoby przekonać konfratrów na sesji generalnej ${ }^{36}$. Uchwała zapewne była adresowana do kilku członków kapituły, którzy wbrew stanowisku kanoniczej korporacji wileńskiej w sporach z biskupem nominatem Mikołajem Stefanem Pacem o administrację dóbr stołowych biskupów wileńskich, forsowali rozwiązania korzystne dla mianowanego, ale nie posiadającego bulli prekonizacyjnej i niekonsekrowanego jeszcze rządcy diecezji. Potwierdza to korespondencja kapituły z biskupem nominatem z tego okresu, zwłaszcza przesłane mu 29 listopada 1675 roku postulaty, wśród których na pierwszym miejscu znalazło się upomnienie i prośba, żeby biskup ,ważniejsze sprawy poruszał na sesjach generalnych, a nie partykularnych"37. W miesiąc później, 30 grudnia, ostrzeżenie w tej sprawie otrzymał prokurator kapitulny. Polecono mu zachować czujność i nie pozwolić „załatwiać poważnych spraw” na sesjach partykularnych ${ }^{38}$. Napomnienia, prośby i groźby, dotyczące wykraczania podczas obrad sesji partykularnych poza ich kompetencje, stanowiły częsty temat obrad posiedzeń generalnych. Szczególnie wyraziście odnotowano je w protokołach z lat $1677^{39}, 1683^{40}, 1743^{41}, 1753^{42}$, $1777^{43}, 1784^{44}$. Rangę sesji partykularnych podniosła decyzja, podjęta 18 maja 1753 roku podczas obrad wiosennej kapituły generalnej. Po raz pierwszy zadekretowano wówczas uchwałę pozwalającą, z racji na konieczność podjęcia niecierpiącej zwłoki ważkiej decyzji, nadać sesji

\footnotetext{
$36 \quad$ Ibidem, s. 178.

37 Ibidem, s. 204.

38 Ibidem, s. 205.

$39 \quad$ Ibidem, s. 472.

40 BLAN, f. 43-226, ACV, t. 18 (1683-1685), s. 36.

$41 \quad$ BLAN, f. 43-234, ACV, t. 26 (1739-1744), s. 342.

42 BLAN, f. 43-236, ACV, t. 28 (1753-1766), s. 11.

43 BLAN, f.43-238, ACV, t. 30 (1777-1783), k. 5v.

44 BLAN, f. 43-240, ACV, t. 31 (1784-1788), k. 24v.
} 
partykularnej moc zgromadzenia generalnego (cum vigore generalis pro hoc solo actu). Uprawnienie to wykorzystano w kilka miesięcy później, gdy na sesji partykularnej 18 września 1753 roku dokonano aktu instalacji mającego udać się na studia do Rzymu kanonika Mikołaja Tyszkiewicza ${ }^{45}$.

Zapadające na sesjach partykularnych uchwały podpisywał najstarszy stażem prałat lub kanonik, zatwierdzał zaś prezydent najbliższej sesji generalnej ${ }^{46}$.

Zamęt spowodowany nominacją na biskupa wileńskiego Mikołaja Stefana Paca, który ponad dziesięć lat zwlekał z przyjęciem sakry i ingresem do katedry, dał taki skutek, że kapitulne gremium odbywało sesje partykularne coraz rzadziej, na tyle rzadko, że w latach czterdziestych XVIII stulecia sprawa zaniepokoiła kancelarię biskupią. Temat ten podjął biskup Michał Zienkiewicz w marcu 1743 roku, kiedy to przygotowując się do wizytacji katedry zapytał kapitułę o przyczynę tego stanu rzeczy. Zgromadzona wówczas na wiosennej sesji generalnej kapituła wyjaśniła, że powodem są zdarzające się w przeszłości przypadki, że na sesjach partykularnych „odmieniano postanowienia uchwalone na generalnych", stąd podjęto uchwałę stanowiącą, aby zbierać się rzadziej i tylko „z powodu wypadków okolicznościowych lub dla czytania akt" ${ }^{47}$. Wyjaśnienie nie zadowoliło rządcy diecezji, który po wizytacji w punkcie piątym dekretu reformacyjnego nie omieszkał wytknąć tego zaniedbania i nakazał kapitule odbywać piątkowe sesje partykularne sumiennie i regularnie ${ }^{48}$.

Analiza akt kapituły pozwala jednak na pewne dopowiedzenie,

History of the Church czym tłumaczyli się duchowni kapitulni przed biskupem. Nieodparcie odnosi się wrażenie, że cotygodniowe sesje piątkowe, głównie z racji na wąski zakres ich kompetencji, po prostu zionęły nudą, a prałaci i kanonicy mieli znacznie ciekawsze pomysły na spędzanie piątkowych wieczorów, niż bezproduktywne, często ciągnące się bez końca, siedzenie w zatęchłym, wilgotnym kapitularzu. Znać to już w 1541 roku, gdy z braku zajęcia na tychże posiedzeniach kapituła ustaliła, aby na każdej piątkowej sesji czytać kolejno po jednym przywileju

$\overline{45} \quad$ BLAN, f. 43-236, ACV, t. 28 (1753-1766), s. 11.

46 BLAN, f. 43-229, ACV, t. 21 (1709-1717), s. 66.

47 BLAN, f. 43-234, ACV, t. 26 (1739-1744), s. 334, 342.

48 BUWil, f. 1-217, Visitatio generalis Ecclesiae Cathedr. Vilnen. ab Il ${ }^{\text {mo }}$ ac $\mathrm{R}^{\text {nd-mo }}$ $\mathrm{D}^{\mathrm{no}}$ Michaele Ioanne Zienkowicz Episcopo Vilnensi Loc: Ord: Anno $\mathrm{D}^{\text {ni }} 1743$ die 13 Mai expedita et per me Victorinum Hryncewicz Canon. Livon. Auditorem causarum curiae Ill $\stackrel{\mathrm{mi}}{\mathrm{i}}$ Loc: Ord: Eiusdem Visitationis Generalis Notarium in sequentia acta redacta, s. 329 . 
kapitulnym ${ }^{49}$. Trudno więc dziwić się, że z początkiem XVII stulecia praktyka odbywania piątkowych posiedzeń upadła niemal zupełnie, a kapituła gromadziła się jedynie na sesjach partykularnych, gdy zachodziła taka potrzeba. Dopiero w 1649 roku, po upomnieniu biskupa, na wiosennej sesji generalnej powzięto uchwałę o wznowieniu sesji piątkowych, na których „z braku zajęcia” polecono czytać zapisaną w statutach rotę przysięgi przewidzianej dla prałatów i kanoników, a następnie przypominać przywileje kapituły, czytając je in extenso „dla należytego spełnienia obowiązku” ${ }^{50}$.

\section{SESJE KAPITUŁY KATEDRALNEJ WILEŃSKIEJ W OKRESIE PRZEDROZBIOROWYM}

Kapituły katedralne były korporacjami powołanymi do pomocy biskupowi w zarządzie diecezją i jako takie funkcjonowały na zasadach przyjętych w korporacjach, co zakłada, że wszelkie decyzje ich dotyczące zapadały kolegialnie na wspólnych posiedzeniach, zwanych ogólnie sesjami lub kapitułami. Służyły one przede wszystkim wzajemnemu porozumieniu się i podjęciu odpowiednich uchwał dotyczących funkcjonowania kapituły zarówno w zakresie jej funkcjonowania jako kolegium, jak też jej aktywności zewnętrznej. Kapituła Katedralna Wileńska wzorująca się w swym ustroju na kapitułach koronnych, w okresie od XV do XVIII stulecia odbywała dwa lub trzy razy w roku w ściśle określonych terminach sesje generalne oraz posiedzenia partykularne, przez które rozumiano zarówno regularnie odprawiane sesje cotygodniowe, jak też sesje nadzwyczajne zwoływane dla omówienia spraw niecierpiących zwłoki. Do tych ostatnich należy też zaliczyć posiedzenia zwoływane w trybie pilnym, tzw. sessiones repertinae. Różniły się one głównie zakresem kompetencji określanych History of the Church przedmiotem obrad, rodzajem podejmowanych uchwał, częstotliwością ich odprawiania i stopniem zobowiązania prałatów i kanoników do obecności. Posiedzenia generalne Kapituły Wileńskiej w okresie przedsoborowym w myśl statutów i przyjętej praktyki - służyły, ogólnie rzecz biorąc, omawianiu i rozstrzyganiu spraw ważniejszych i zasadniczych, sesje zaś partykularne, poświęcone były sprawom mniej ważnym, często dyktowanym bieżącymi potrzebami korporacji.

Słowa kluczowe: Wilno, diecezja wileńska, kapituła katedralna, sesja kapitulna generalna, sesja kapitulna partykularna, korporacja kanonicka, notariusz kapitulny, prałat, kanonik. 


\section{Bibliografia:}

\section{Źródła archiwalne:}

1. Lietuvos Mokslų Akademijos Biblioteka - dział rękopisów

- fond 43, nr 210-240, Acta Capituli Vilnensis.

- fond 43, nr 155, Statuta inclitae Ecclesiae Cathedralis tam a Venerabili Capitulo quam eius Pontificibus edita tum a Sanctissima Sede Apostolica confirmata, [ok. 1584].

2. Vilniaus Universiteto Biblioteka - dział rękopisów, fond 1, nr 217, Visitatio generalis Ecclesiae Cathedr. Vilnen. ab $\mathrm{Il}^{\frac{\mathrm{mo}}{2}}$ ac $\mathrm{R}^{\text {nd-mo }} \mathrm{D}^{\text {no }}$ Michaele Ioanne Zienkowicz Episcopo Vilnensi Loc: Ord: Anno D ${ }^{\text {ni }} 1743$ die 13 Mai expedita et per me Victorinum Hryncewicz Canon. Livon. Auditorem causarum curiae Ill $\frac{\mathrm{mi}}{\mathrm{L}}$ Loc: Ord: Eiusdem Visitationis Generalis Notarium in sequentia acta redacta.

3. Biblioteka Polskiej Akademii Nauk w Krakowie - dział rękopisów, sygn. 1963, Statuta inclite Ecclesiae cathedralis Vilnensis ac Sacre divi Stanislai sedis tam a venerabili Capitulo, quamcuius pontificalibus edita et a $\mathrm{S}^{\mathrm{ma}}$ Sede Apostolica confirmata A. 1515.

\section{Źródła drukowane:}

1. Constitutiones synodorum Metropolitanae Ecclesiae Gnesnensis provincialium, red. J. Wężyk, Cracoviae 1630.

2. Kurczewski J., Kościót zamkowy czyli katedra wileńska w jej dziejowym, liturgicznym, architektonicznym i ekonomicznym rozwoju, cz. 3, Wilno 1916.

3. Ulanowski B., Materiaty do historii ustawodawstwa synodalnego w Polsce w XVI w. [w:] Archiwum Komisji Prawniczej, t. 1, Kraków 1895.

History of the Church

4. Vilniaus ir žemaičių katedru kapitulu statutai, red. W. Pawlikowska-Butterwick, L. Jovaiša, Vilnius 2015.

\section{Opracowania:}

1. Bouix D., Tractatus de capitulis, Parisiis - Lugduni 1852.

2. Federkiewicz J., Kapituła przemyska obrzadku łacińskiego (reprint z Kroniki Diecezji Przemyskiej z lat 1908-1913), Przemyśl 2013.

3. Góralski W., Kapituła katedralna w Ptocku XII-XVI w. Studium z dziejów organizacji prawnej kapitut polskich, Lublin 1978.

4. Góralski W., Posiedzenia kapituty kolegiackiej w Puttusku (XV-XX w.), „Studia Płockie”, 4(1976), s. 185-197.

5. Kurczewski J., Biskupstwo wileńskie od jego założenia a $\dot{z}$ do dni obecnych, Wilno 1912.

6. Pałka P., Posiedzenia katedralnej kapituty chetmskiej obrządku łacinskiego w świetle materiatów archiwalnych, „Roczniki Teologiczno-Kanoniczne”, 19(1972), z. 5.

7. Zachorowski S., Rozwój i ustrój kapituł polskich w wiekach średnich, Kraków 1916, s. 158. 